\title{
Behavioral Studies in the Middle East on Culture, Risk Perception and Decision-Making
}

\author{
Syed Sultan Mohiuddin, Mahmoud Salem Al Alawi
}

\begin{abstract}
This paper studies the Behavioral studies on the Middle East on culture, risk perception and decision-making. Cultural risk is evaluated as more essential in the business environment than political, budgetary, and financial danger. The most basic danger components are not adequately incorporated into the procedure of nation's danger measures, which are frequently utilized as a hotspot for country-specific risk data.
\end{abstract}

Keywords: Culture, risk perception, decision making, Middle East, behavior

\section{Introduction}

Hofstede's[1]examination of social measurements consolidated an examination of the Arab world. His Arab world study fused the countries of Egypt, Iraq, Kuwait, Lebanon, Libya, Saudi Arabia, and the United Arab Emirates. A divide of the studies [2] that were done by Arabic scientist tried to rehash Hofstede's study in other Arab countries. Anwar's [2] subjective study inspected Hofstede's five estimations in Jor-danian culture and stood out it from Hofstede's out-comes. The study's results in Jordan facilitated Hofstede's results in the Arab World, which discovered high Power Distance, Masculinity, and Uncertain-ty Avoidance estimations, and low Individualism and Long-Term Orientation. Tawfeeq's [3] study was done on the Tunisian culture by meeting the IT officials and senior executives of the primary five telecom associations in Tunisia. The results of the study facilitated Hofstede's eventual outcomes of the Arab world aside from the Masculinity estimation that was found to be lower in Tunisia.

\section{Background}

The Middle East insinuates a socio-political and social zone that does not have correct limits [4]. With the ultimate objective of this extraordinary issue, we get a more broad importance of the area as portrayed by all inclusive associations to consolidate all locale connecting from Morocco to Turkey close-by the southern and eastern shores of the Mediterranean as far east as Iran, and south to Sudan and Yemen (Ahmed, 2008). The term "Middle East" was at first exhibited in 1901 by U.S. boss maritime officer Alfred Mahan (Ali, 1999), going before it was em-propped in power correspondence of Britain (Ali, 1999). On the other hand, given the different characteristics of eth-nicities, vernaculars, and religions in the area, the level of consistency expected in a significance of a district may not be a honest to goodness impression of its contrasting reality. The Middle East area has collected what's coming to it of extension in academic written work and current news. A considerable measure of these creations, regardless, concentrate on political turmoil and conflicts in the area (Kamalipour, 1997). As indicated by the too much negative news scope depicting the Middle East as an area in steady turmoil, one would envision that it will be a unimportant business for multinational endeavors (MNEs). However, the
Middle East is home to various of the world's greatest MNEs, most of which value an oversaw advantage from their operations in the area (Kavoossi, 2000). Truth be told, the summary of MNEs working in the region resembles a program of the Fortune 500.

In the settlement and retail divisions, MNEs have succeeded in making themselves as the mind-boggling players and control a colossal offer of the business segment in all Middle Eastern countries. Furthermore, in the fast food industry, MNEs have made an a dependable balance and invaded every corner and cre-bad habit of the unlimited Middle Eastern business. The region of multinational endeavors (MNEs) in the Middle East is not another ponder. The recorded background of present day MNEs in the Middle East can be taken after back to Ottoman time. The Ottoman bank was set up in 1856 in the Galata business area of Istanbul, the capital of Ottoman Empire. This was a joint meander between British premiums, the bank de Paris et des Pays-Bas of France (Bank of Paris and the Netherlands - at present known as BNP Paribas) and the Ottoman treasury. Likewise, distinctive MNEs, for ex-sufficient, Nestle', discovered their business reinforcements, exceptionalists, and business specialists, in genuine business urban ranges, for instance, Istanbul, Izmir, Jafa, Alexandria, and Cairo, and also in various parts of the domain (Koese, 2008). Koese (2008) fights that the ethni-cally, religiously, and etymologically distinctive Otto-man capital wound up being a key get ready re-hunt focus down Nestle (and possibly for some diverse MNEs), enabling the association to develop the key and coordination aptitudes anticipated that would succeed in the heterogeneous and complex overall commercial focus

Considerations and showcasing instruments developed in Istanbul, as demonstrated by Koese (2008: 727), "would later be passed on to European market" - early confirmation of banter data trade. For instance Saudi Aramco has both the world's greatest evil spirit strated foul petroleum holds, at more than 260 billion barrels $(4.1 \times 1010 \mathrm{~m} 3)$, [7] and greatest step by step oil production.[8] Saudi Aramco claims, works and develops all imperativeness resources arranged in Saudi Arabia. As showed by a 2015 Forbes report, Aramco is said to be the world's greatest oil and gas association. Distinctive associations have been selected different qualities for each estimation. Unmistakable organisations have either high or low power partition, high or low helplessness avoidance, they are either masculine or ladylike or autonomous or

Volume 6 Issue 1, January 2017 


\section{International Journal of Science and Research (IJSR) \\ ISSN (Online): 2319-7064}

Index Copernicus Value (2015): 78.96 | Impact Factor (2015): 6.391

collectivist. Each of these estimations and their qualities give an indication of the direct a man from a particular gathering might be depended upon to appear. Individuals from individualistic, masculine organisations with low power partition and low instability evading are thought to be high brave individuals as differentiated and individuals from collectivist, woman working associations with high power detachment and high powerlessness avoidance. These social underpinnings affect a particular's risk wisdom and threat producing limit and thus have a results on their basic leadership.

Hofstede's (1980) social framework was proposed in 1984 and starting now and into the foreseeable future vital changes have happened general including various new social amalgamations, realizing a couple cir-cumstances that are unaccounted for by this structure. For example Chinese (Hofstede, 1980a) are collectivist and according to Hofstede, they are less danger taking, yet a close study (Weber and Hsee, 1998) of Americans and Chinese found that Chinese are more peril taking when diverged from Americans who are individualists. Hofstede (1980a, b) in his finish research of in excess of 50 national social requests, per-ceived North American and comparative Anglo social requests (Australia, New Zealand and the United Kingdom of Great Britain and Northern Ireland) as exceedingly dissident. Obviously, different Pacific edge nations, for example, Singapore and Hong Kong, China are more collectivist. Office hypothesis, which is essentially a hypothesis of self-wander, might be more connected with strongly individualistic nations. No ifs ands or buts, it is enrapturing to figure whether association hypothesis could have been made to the degree it has been in any overall population other than an intellectual one. The general considered out and out showing self-theory might not have jumped out at compelling voices in a collectivist society. Affiliation theories expect an overall population where thought is arranged on a specific's dedication to oneself, and where such self-dazzled conduct is the standard, and in like manner socially exemplary. It is conceivable that in a more collectivist society, where specific accomplishment is less respected, and individual responsibility to one's affiliation is revolved around, administrators would be less enthusiastic to take practices in their own particular self-intrigue.

The relationship between prospect hypothesis and society is less clear. Kahneman and Tversky (1979) exhibited that couple of consequences of prospect theory were essentially comparable among powers from Sweden, Israel and America. This is persisting with the point of view that prospect hypothesis is a hypothesis of individual human astuteness and data dealing with and in this manner liberates of society. Then again, they moreover observe that "the bearers of significant worth are changes in riches or welfare, instead of last states" (p. 277), and insinuate the case that a given level of riches may propose sad disheartening for one individual and phenomenal wealth for a substitute. To the degree that an understanding and/or authentic levels of these factors are society related, society may affect affirmations and consequently choice decisions (Hofstede, 1980b). Thusly, it is conceivable that prospect theory is society particular.
Hofstede (1980a) perceived a socially based measure of aggregate resistance for frailty, which he named "insecurity evasion", which may have affect in basic leadership under hazard. Singapore, Hong Kong, and Red China were appropriately satisfying with the instabilities of life, while Anglo/North American nations, for example, UK, USA, Canada, Australia and New Zealand were more precariousness evading, and Pakistan exceedingly so. To the degree that a more vital solace with shakiness is reflected in a higher repugnance for hazard everything, the Confucian estimations of persistence joined with higher danger taking may no ifs ands or buts give the motivation to unmistakable choices under shortcoming.

The low uncertainty maintaining a strategic distance from of the Pacific Rim nations proposes two conceivable impacts. At to start with, it might just instigate an aggregate more basic ability to shoulder business dangers. In any case, there might be diverse impacts in a conflictingly created uplifted decision circumstance, where even the doubtlessly comprehended helplessness keeping up a vital separation from North American social orders are eager to put it all on the line to avoid adversities. Arranging may thusly serve as a genuine transformer to social weakness. A less flimsiness dodging society should, subsequently, demonstrate an improved sorting out result.

Enter decision making in multicultural affiliations is done by social events as they can exploit the different data and aptitudes of its workforce and decide distinct advantage (Brazzel, 1991). Contrasts enable relationship to examine a wide blended pack of decisions, put forward by unmistakable people. Varying qualities can be portrayed with respect to human complexities that accept a crucial part in the lifestyle and operation of affiliations (Brazzel, 1991). Rizzi and Berry (2000) prescribed that social housings of reference impact basic leadership in get-togethers. Weber, Hsee and Sokolowska (1998) secured that boss fluctuate on demographic estimations, for instance, age, sex and ethnicity. Meahwhile, Noorderhaven (1995) pondered that the decision making methods are energetically influenced by important factors, for instance, the plan of the organization accumulate, the characters of the pioneers, and the definitive structure and social.

\section{Risk Perception}

Cultural risk is assessed as more fundamental in the business environment than political, budgetary, and money related peril. The most fundamental risk parts are not enough fused into the strategy of country threat measures, which are much of the time used as a hotspot for country-specific peril information. Respecting peril organization strategies, taking a between est firms use generally easygoing systems rather than composed supporting or security items. Individuals observations are influenced by numerous risk related and setting related characteristics of the threat circumstance. These consolidate the photos of dread associated with the peril, whether the risk is joined by any countervailing benefits, whether those at threat are familiar with the threat, and whether the risk is before long controllable. On a more aggregate level the evident dispersal of perils and focal points among and between get-togethers and masses is an

Volume 6 Issue 1, January 2017 www.jijsr.net 


\section{International Journal of Science and Research (IJSR) \\ ISSN (Online): 2319-7064}

Index Copernicus Value (2015): 78.96 | Impact Factor (2015): 6.391

imperative driver for social concern.

\section{Cross cultural Risk Management}

Additionally, according to Barto and Martin (1998), multifaceted organization is a strategy in which the administration considers social differentiations and the ability to advertisement just to particular associations. The lifestyle of an overall population serves to add to the state of mind of the individuals in the overall population. Association controls the mind and effects the ways people see matters, act politically, settle on and compose decisions, manage their lives and essentially impacts the ways they think. One should not seclude care and social care. One needs to go past the criticalness of association itself to have a prevalent cognizance of how culture impacts our own particular lives. It is that with the begin of the globalization, another structure of correspondence among the countries had been created which is as the multinational affiliations. This is con-tended in this study with respect to the activities of MNCs, the structure of the overall trade etc. These multinational portions were started to take the upside of the joint tries, key accomplice ships, abroad reinforcements and allowing understandings to acknowledge the remote characters when required, like that when they oblige maintaining a strategic distance from the obligation obstacles, securing occupations or obtaining predominant bits of the general business. The worldwide economy in which the MNCs work has been depicted as a framework in that any organizations, national economies or things are on an exceptionally fundamental level non - existent. It is that UAE, with the point of view motivation behind transforming into an industrialized nation, it had intelligently opened its market to globalization by changing the directions and trade for the concerning organizations. As the universe of overall business streams and surges in various headings, the bit of the cross - social organization remains a noteworthy issue. This study has been coordinated in the setting of multicultural affiliation and spotlights on the different refinements. This re-seek chiefly focuses in transit of life and as to how it shapes the conviction of an individual and the qualities moreover its effects on the lead.

As discussed above association and organisation grouped qualities shape a particular's ability to put it all on the line. In a multicultural various leveled setting, social affairs of people from particular social foundation are called upon to evaluate elective choice, which in this manner are affected by how get-togethers see dangers. In this way it can be gathered that multifaceted contrasts in risk acknowledgment and peril taking have genuine repercussions on the definitive basic leadership technique which this investigation hopes to examine.

\section{Theoretical Background}

A Culture Society, with its different definitions and recommendations, has always been difficult to tie (Braithwaite, Hyde, and Pope, 2010; Martin, 2002). Anthroposensible and sociological methodologies have a tendency to depict so-ciety as a game plan of atmosphere, emotions, traditions, values and practices which are conceded by a social af-reasonable (Alvesson, 2002; Ashkanasy,
Wilderom, and Peter-child, 2000). The get-together might be depicted concerning definitive issues, topography, ethnicity, religion, or some other alliance. The attributes which portray the social gathering might be given as sug-gestions, pictures, dialect, knickknacks, oral and framed custom and differing implies (Brown, 1995). One of the isolating furthest reaches of these signs of a bun-dle's overall population is to make a substitute personality and therefore give a schedules by which parts of the party can disengage themselves from unmistakable social gatherings (Throsby, 2003). Society, in this perspective, restrains as a sorting out contraption (Schein, 1997). Social com-plexities can be translated comparatively as separations in the emotions individuals hold about the way the world works and around each other, actuating the decision of one game plan of procedures rather than another and along these lines, managing one course of action of affiliations and improvement as opposed to a substitute (Greif, 1994). Establishments are as should be surrounded and held together by the social behvaior hold around each other and the world.

\section{Organizational Cultures}

As appeared by Lewis (2002) a thorough criticalness of dynamic culture has indicated risky, in any case it is all around thought to be the gave qualities, sentiments and suppositions that exist among workers inside an association that help helper and bearing conduct (Schein, 1991). Complete associations are in light of present circumstances perceived to be a generally comprehensive and multidimensional thought that is generally picked and socially developed (Hofstede, Neuijen, Ohayv, and Sanders, 1990). Tyrrell (2000) illuminated that different leveled social conduct is consistently being coordinated as it is an emanant property of human correspondence. The qualities and emotions that rising up out of the propelling trade and practices among get-together parts change into a wellspring of reference for what is regarded palatable or forbidden in an alliance with respect to awesome and horrible conduct (Kusluvan and Karamustafa, 2003).

The qualities and sentiments that underlie defini-tive society likely reflect what is most significant to the originators and/or affiliation pioneers as they are air conditioning countable for the vision and motivation driving the alliance, and clearly address and support the in-side qualities and emotions through their own conduct (e.g., Schein, 1991; Scheres and Rhodes, 2006; Weese, 1995; Wilkins, 1983). Conclusive society is additionally demonstrated through part discourse and lead furthermore different leveled rehearses (Schein, 1985). It is likewise related to by affiliation antiques, dress regulations, get ready gages, organizations, routinely ex-amined affiliation stories, and how an affiliation administers emergencies, all of which reflect an association's qualities, emotions, and major suppositions (Beach, 2006; Dastmalchian, Lee, and Ng, 2000; Detert, Schroeder, and Mauriel, 2000; Rafaeli and Pratt, 2006; Smith and Shilbury, 2004). The change of genius gressive society has been depicted in various ways. Exactly when all is said in done, complete society is incorporated a common observation and things that are presented among dynamic parts. These gave things solidify, yet are not restricted to, theories, conviction systems, values, presumptions, needs, affirmations, rules, 


\section{International Journal of Science and Research (IJSR) \\ ISSN (Online): 2319-7064}

Index Copernicus Value (2015): 78.96 | Impact Factor (2015): 6.391

platitudes, lead, heavenly individuals, and customs. Martin and Meyerson (1988) compacted each social sign as practices, out of date, and substance subjects. Practices can be depicted as guidelines, methodology, and standards of a connection, and can be either formal or agreeable. A couple people respect a connection's capacities, ceremonials, and customs as different leveled society (Trice and Beyer, 1984). These are reliably called out of date (Schein, 1992) and are committed to consistent understandings. Two or three masters viewpoint honest to goodness society as control and ex-change instruments (Jones, 1983; Wilkins and Ouchi, 1983) and a wellspring of kept up playing point (Barney, 1986; Fiol, 1991). To other connection pros, society is a representation of important emotions, suppositions, and qualities allowed by genuine parts (bargain and kennedy, 1982; Schein, 1992). These are the sub-position topics to which Martin and Meyerson (1988) hint.

\section{Conclusion}

From the present study with respect to the United Arab Emirates, it can be watched that, it serves as an inside offering jobs to people from around 200 countries around the world. Thusly, as people from grouped countries and varying social establishments collaborate in UAE, there in actuality exist social differentiations and conflicts in the business systems of the affiliation. The major conflicts are seen to rise in the methodology of dangers taking and basic leadership in the associations. Besides, more than everything, the lifestyle and working of organizations in UAE is totally assorted It can be subsequently contemplated that, people from other social foundations find hard to take after the style of correspondence in the UAE; differentiates in correspondence; social convictions and practices; confusions and to keep up or think in regards to the Islamic laws of UAE.

\section{Acknowledgment}

The authors wish to thank Dr. Abdul Rahman Jassim Al Hammadi for his valuable support to the research. This research paper is supported in part of authors' $\mathrm{PhD}$ Thesis.

\section{References}

[1] Hofstede G, Hofstede GJ, Minkov M. Cultures and organizations: Software of the mind. London: McGrawHill; 1991 Jan.

[2] Anwar SA, Sohail MS. Festival tourism in the United Arab Emirates: First-time versus repeat visitor perceptions. Journal of Vacation Marketing. 2004 Apr $1 ; 10(2): 161-70$

[3] Tawfeeq, R. Z. (2003) Tuberculin reactivity among health care workers at King Abdulaziz University Hospital, Saudi Arabia.

[4] Budhwar P, Mellahi K. Introduction: human resource management in the Middle East. The International Journal of Human Resource Management. 2007 Jan $1 ; 18(1): 2-10$

[5] Gultural Differences Among Nations', International Studies of Management \& Organization 13 (Spring/Summer), 46-74.

[6] Hofstede G. Culture's consequences: National differences in thinking and organizing. Beverly Hills, Calif.: Sage. 1980..

[7] Hofstede G. The interaction between national and organizational value systems [1]. Journal of Management Studies. 1985 Jul 1;22(4):347-57.

[8] Hofstede G. The business of international business is culture. International business review. 1994 Mar $1 ; 3(1): 1-4$.

[9] Hofstede G. Management of multicultural structures. Economic, Bucarest. 1996..

[10] Hofstede G, Bond MH. Hofstede's culture dimensions an independent validation using Rokeach's value survey. Journal of cross-cultural psychology. 1984 Dec 1;15(4):417-33..

[11] Hofstede G. Motivation, leadership, and organization: do American theories apply abroad?. Organizational dynamics. 1980 Jun 1;9(1):42-63.

[12] Hofstede G. Culture's consequences: International differences in work-related values. sage; $1984 .$.

[13] Hofstede G, Bond MH. The Confucius connection: From cultural roots to economic growth. Organizational dynamics. 1988 Mar 1;16(4):5-21..

[14] Hofstede G. Culture's consequences: International differences in work-related values. sage; 1984 ..

[15] Hofstede G, Hofstede GJ, Minkov M. Cultures and organizations: Software of the mind. London: McGrawHill; 1991 Jan.

[16] Koshak, E. A., \& Tawfeeq, R. Z. Tuberculin reactivity among health care workers at King Abdulaziz University Hospital, Saudi Arabia.2003.

[17] Ahmed Hussein M. Costs of environmental degradation: An analysis in the Middle East and North Africa region. Management of Environmental Quality: An International Journal. 2008 Apr 18;19(3):305-17h.

[18] Ali, A.J., 1999. Middle East competitiveness in the 21st century's global market. The Academy of Management Executive, 13(1), pp.102-108..

[19] Kamalipour YR. The US media and the Middle East: Image and perception. Greenwood Publishing Group; $1997 .$.

[20] Kavoossi M. The globalization of business and the Middle East: Opportunities and constraints. Greenwood Publishing Group; 2000..

[21] Kose MA, Otrok C, Prasad ES. Global business cycles: convergence or decoupling?. National Bureau of Economic Research; 2008 Oct 2 ..

[22] Hofstede, G.. Culture and organizations. International Studies of Management \& Organization, 1980, 10(4), $15-41$.

[23] Weber, E. U., \& Hsee, C. Cross-cultural differences in risk perception, but cross-cultural similarities in attitudes towards perceived risk. Management science, 44(9), 1998, 1205-1217.

[24] Kahneman, D., \& Tversky, A. Prospect theory: An analysis of decision under risk. Econometrica: Journal of the econometric society, 1979, 263-291.

[25] Brazzel, M. Building a culture of diversity in the cooperative extension system: A paper to foster dialogue and discussion about pluralism in extension. In ECOP and ES-USDA National Diversity Strategic Planning Conference, Denver, Colorado. 1991.

[26] Auer-Rizzi, W., \& Berry, M. Business vs. cultural frames of reference in group decision making: 


\section{International Journal of Science and Research (IJSR) \\ ISSN (Online): 2319-7064 \\ Index Copernicus Value (2015): 78.96 | Impact Factor (2015): 6.391}

Interactions among Austrian, Finnish, and Swedish business students. Journal of Business Communication, 37(3), 2000, 264-288.

[27] Weber, E. U., Hsee, C. K., \& Sokolowska, J. What folklore tells us about risk and risk taking: Crosscultural comparisons of American, German, and Chinese proverbs. Organizational behavior and human decision processes, 75(2), 1998, 170-186.

[28] Noorderhaven, N. G. Strategic decision making.1995.

[29] Martin, D. C., \& Bartol, K. M. Performance appraisal: Maintaining system effectiveness. Public Personnel Management, 27(2), 1998, 223-230.

[30] Hyde, P., Pope, C., \& Braithwaite, J. Conclusion: Culture and Climate in Health Care OrganizationsEvidentiary, Conceptual and Practical progress. In Culture and Climate in Health Care Organizations. Palgrave Macmillan UK. 2010, pp. 208-212

[31] Alvesson, M. Postmodernism and social research. Open University. 2002.

[32] Ashkanasy, N. M., Wilderom, C. P., \& Peterson, M. F. (2000). Handbook of organizational culture and climate. Sage.

[33] Brown, R. P. Estimating remittance functions for Pacific Island migrants. World development, 25(4), 1995, 613-626.

[34] Throsby, D. Determining the value of cultural goods: How much (or how little) does contingent valuation tell us?. Journal of cultural economics, 27(3-4), 2003, 275285.

[35] Schein, O. D., MUÑO, B., Tielsch, J. M., BandeenRoche, K., \& West, S. Prevalence of dry eye among the elderly. American journal of ophthalmology, 124(6), 1997, 723-728.

[36] Greif, A. Cultural beliefs and the organization of society: A historical and theoretical reflection on collectivist and individualist societies. Journal of political economy, 1994, 912-950.

[37]Lewis, C. C. Lesson study: A handbook of teacher-led instructional change. Research for Better Schools. 2002.

[38] Hofstede, N. Ohayv, and Sanders. Measuring organizational cultures: A qualitative and quantitative study across twenty cases. Administrative Science Quarterly, 53, 1990, 286-316.

[39] Kusluvan, Z., \& Karamustafa, K. Organizational culture and its impacts on employee attitudes and behaviors in tourism and hospitality organizations. Managing employee attitudes and behaviors in the tourism and hospitality industry, 2003, 453-485.

[40] Schein, E. H. Defining organizational culture. Classics of organization theory, 3, 1991, 490-502.

[41] Wallace, M., \& Weese, W. J. Leadership, Organizational Culture, and Job Satisfaction in Canadian CA Organizations. Journal of Sport Management, 9, 1995, 182-193.

[42] Wilkins, A. L., \& Ouchi, W. G. Efficient cultures: Exploring the relationship between culture and organizational performance. Administrative science quarterly, 1983, 468-481.

[43] Beach, M. C., \& Inui, T. Relationship-centered care. Journal of General Internal Medicine, 21(S1), 2006, S3S8.

[44] Dastmalchian, A., Lee, S., \& Ng, I.. The interplay between organizational and national cultures: a comparison of organizational practices in Canada and South Korea using the Competing Values Framework. International Journal of Human Resource Management, 11(2), 2000, 388-412.

[45] Detert, J. R., Schroeder, R. G., \& Mauriel, J. J. A framework for linking culture and improvement initiatives in organizations. Academy of management Review, 25(4), 2000, 850-863.

[46] Pratt, M. G., \& Rafaeli, A. Artifacts and Organizations: Understanding Our" Object-ive" Reality. Artifacts and Organizations. Beyond Mere Symbolism, 2006, 279288.

[47] Smith, A. C., \& Shilbury, D. Mapping cultural dimensions in Australian sporting organisations. Sport Management Review, 7(2), 2004, 133-165.

[48] Martin, J., \& Meyerson, D. Organizational cultures and the denial, channeling and acknowledgement of ambiguity. Managing ambiguity and change, 93, 1988, 126.

[49] Trice, H. M., \& Beyer, J. M. Studying organizational cultures through rites and ceremonials. Academy of management review, 9(4), 1984, 653-669.

[50] Jones, V. F. Braid groups, Hecke algebras and type II1 factors. Geometric methods in operator algebras, 1983, $123,242-273$

[51] Wilkins, A. L., \& Ouchi, W. G. Efficient cultures: Exploring the relationship between culture and organizational performance. Administrative science quarterly, 1983, 468-481.

[52] Barney, J. B. Strategic factor markets: Expectations, luck, and business strategy. Management science, 32(10), 1986, 1231-1241.

[53] Fiol, C. M. Managing culture as a competitive resource: An identity-based view of sustainable competitive advantage. Journal of management, 17(1), 1991, 191211.

[54]Deal, T. E., \& Kennedy, A. A. Corporate cultures: The rites and rituals of organizational life. Reading/T. Deal, A. Kennedy.-Mass: Addison-Wesley, 2, 1982,98-103.

[55] Schein, E. H. How can organizations learn faster?: the problem of entering the Green Room. 1992.

Volume 6 Issue 1, January 2017

www.ijsr.net

Licensed Under Creative Commons Attribution CC BY 